\title{
Features of forming an invertebrate fauna in technogen environment (Kriviy Rig, Ukraine)
}

\author{
${ }^{1}$ Y. Kul'Bachko $-{ }^{1}$ O. Pakhomov $-{ }^{2}$ O. Didur $-{ }^{2}$ I. Loza \\ ${ }^{1}$ Department of Zoology and Ecology, Biology, Ecology and Medicine Faculty, Dnepropetrovsk, Ukraine \\ ${ }^{2}$ Institute of Biology, Dnepropetrovsk, Ukraine, \\ irinaloza@hotmail.com
}

SUMMARY

\begin{abstract}
The features of invertebrate fauna forming in conditions of technogen pressure (Kriviy Rig, Ukraine) were studied. The taxonomic composition, dominance structure and correlation of soil invertebrates'functional groups in the large industrial enterprises were examined. It had been found that a small thickness of the soil layer as a habitat for ground animals causes the depletion of taxonomic composition, species richness and decrease the total number of soil invertebrates. Gastropoda molluscs in conditions of technogen pressure are the most adapted to stresses group of invertebrates.
\end{abstract}

Keywords: taxonomic composition, dominance structure, environment transformation, soil invertebrates

\section{INTRODUCTION}

Ukraine has more than 80 fields, $70 \%$ of which found in Kriviy Rig iron ore basin. More than 90 enterprises in various sectors of ferrous metallurgy function in Kriviy Rig basin. Also there are located numerous chemical companies.

As a result of long-term activity metallurgical and chemical enterprises of national magnitude is environment irreversible transformation (Леонов, 1970; Малахов, 2003). A comprehensive pollution of soil, air, surface and groundwater is happened. In this local anthropogen region on the newly-formed technogen landscapes were formed special technogen ecosystems (Травлеев, 2000; Сметана, 2007; Зубов et al., 2007). They have such specific characteristics: 1) block, not component structure, 2) absence of further selfdevelopment opportunities in connection with domination the influence of technogen unit, and 3) the main event determines their existence, is human activity. It is based primarily on the people needs.

In these conditions is forming the specific fauna of soil invertebrates, which appears as changes of taxonomic composition, quantity, dominance structure and correlation of functional groups etc. (Криволуцкий, 1994; Воробейчик, 1998; Миркина et al., 2003; Сметана and Сметана, 2005).

\section{MATERIAL AND METHODS}

The representatives of soil mesofauna were as an object of research at sites of JSC "Kriviy Rig Saturnine Red Plant" (Plots 1 and 2) and at sites located in the territory of "Arselormyttal Kriviy Rig" (Plots 3 and 4). Researches had conducted in period of June and July 2009-2010. Brief descriptions of investigated areas are given below.

\section{Territory of "Kriviy Rig Saturnine Red Plant"}

Plot \# 1. Vegetation cover on this plot is presented to grass (Elytrigia repens + Poa nemoralis + Poa angustifolia) plant associations. In the vegetation structure of this area the weed (ruderal) species are dominated. In the structure of arboreal stands was dominated oleaster (Elaegnus angustifolia L.), many trees had a dried top, die off. Soils of this territory are characterized as a technogenic and accumulative. The leading factors of human impact were sedimentation of calcium and iron containing dust and pollution by slag.

Plot \# 2. Vegetation cover consisted of grass (Elytrigia repens + Poa angustifolia) plant associations with domination of weed (ruderal) species and one that are approach in their ecology to ruderal. Artificial arboreal stands were very tenuous. All representatives of stands are frustrated, height about $1 \mathrm{~m}$, with dry top and forming a shrub. Soils characterized as a technogenic mosaic. The leading factor of human impact is slag pollution.

\section{The territory of JSC "Arselormyttal Kriviy Rig"}

Plot \# 3 is presented to grass associations (Poa angustifolia + Elytrigia repens). As a dominant there are weed (ruderal) groups and species that have ecological adaptations similar to ruderals. Soils are technogenic sedimentation and accumulative. The leading factors of human impact are dust sedimentation and slag pollution.

Plot \# 4 is presented to artificial arboreal stands partly carved. Remains of trees provide an abundant grows. In structure of vegetation are dominated grass ruderal species. Soils are technogenic sedimentation and accumulative.

Capturing of invertebrates had conducted in accordance with standard of soil-zoological methods.

\section{RESULTS AND DISCUSSION}

\section{Soil mesofauna of territory JSC "Kriviy Rig Saturnine} Red Plant"

Plot \# 1. In artificial stands of this site were founded 17 species of soil mesofauna representatives belonging to 6 classes. The total number of invertebrates was 95 specimens $\mathrm{m}^{-2}$. Numbers of representatives of separate classes had significant fluctuations. The highest number of typical for molluscs representatives was 45 specimens $\mathrm{m}^{-2}$ and insects 22 specimens $\mathrm{m}^{-2}$ (Figure 1). Number of earthworms representatives in 2-4 times lower than previous taxons. The minimum quantity 4 specimens $\mathrm{m}^{-2}$ was identified for Diplopoda. 
Figure 1: Structural organization of soil mesofauna representatives in artificial tree plantation, territory of JSC “Kriviy Rig Saturnine Red Plant" (Plot \# 1)

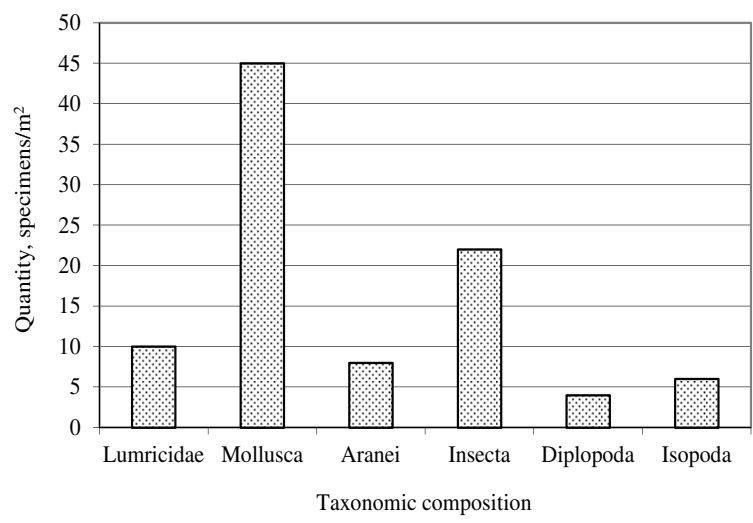

High number of wood-louse, earthworms, and molluscs is explained to higher location of groundwater from surface. This fact in conditions of strong technogenic impact creates favorable hydrothermal conditions for their existence.

Analyzing the domination structure of mesofauna representatives on the level of classes, it should be noted that representatives of molluscs were superdominants (47\%), insects were dominants (24\%), Diplopoda and crustaceans are characterized as recendents $(4 \%$ and $6 \%$ respectively).

In relation to taxonomic of mesofauna representatives the class of insects was the most widely represented (Insect, 15 species). In composition of Insect class comprise representatives of Elateridae, Coccinellidae, Carabidae, Staphylinidae, Formicidae, Silphidae, Pyrrhocoridae. Besides insects in artificial tree stands the high species richness was observed for the class Mollusca which was represented by 4 types.

The functional structure of soil invertebrates' communities is indicator of ecosystem features including disturbance. The composition of their functional groups on the investigated territory is presented on Figure 2.

Figure 2: Functional organization of soil mesofauna representatives in artificial tree plantations, territory of JSC “Kriviy Rig Saturnine Red Plant” (Plot \# 1)

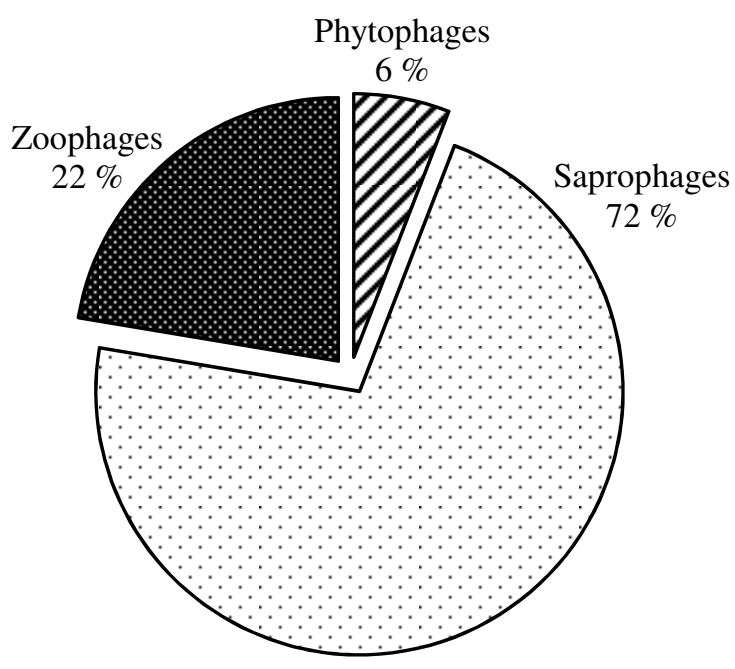

Presence of leaf litter and favorable hydrothermal regime of this area create the optimal conditions for saprophages existence $(72 \%)$. Phytophagous share is low $(5 \%)$, which allows to zoophagous $(23 \%)$ make their regulation function in these climatic conditions.

Plot \# 2. This territory with weed vegetation was situated near $1 \mathrm{~km}$ away from JSC "Kriviy Rig Saturnine Red Plant". Subsoil was gravel and topsoil was a layer of humus thickness only $10-15 \mathrm{~cm}$. This type of ground causes the unfavorable conditions for development and grows of artificial tree plantations and formation of soil mesofauna complex. Under such conditions, the main factor affecting to representatives of mesofauna is hydrothermal regime, not industrial pollution.

Mesofauna is represented by inhabitants of leaf litter-molluscs, spiders, and insects. Their number is twice less than at the Plot \# 1. Ratio between taxons of invertebrates is shown in Figure 3. However, decreases number of invertebrate species their richness is reduced in 3 times. Thus, the number of mollusks species is reduced from 4 to 1 specimen, insects from 10 to 3 .

Figure 3: Taxonomic composition of soil mesofauna representatives in the territory of weed vegetation, JSC

“Kriviy Rig Saturnine Red Plant” (Plot \# 2)

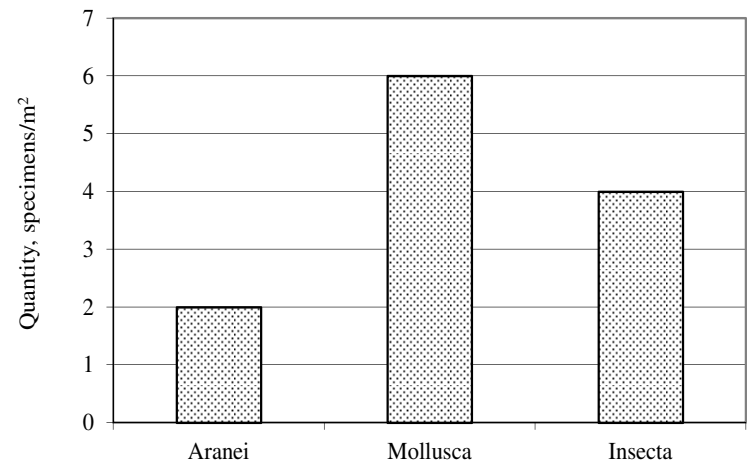

Existence conditions impact both taxonomic composition of animals and structure of their dominance. Because of invertebrates taxons reduction there is no define differentiation of the dominance structure. As superdominants of studied territory the molluscs had the highest number 6 specimens $\mathrm{m}^{-2}$ $(50 \%)$, insects $(34 \%)$, and spiders $(16 \%$ from total population).

At the species level was observed the highest number of molluscs $\left(6\right.$ specimens $\mathrm{m}^{-2}$ representatives of Chondrula tridens) but it was 3.2 times lower comparatively with number of them in artificial tree plantations in impact zone of "Kriviy Rig Saturnine Red Plant".

Correlations of different functional groups of soil mesofauna in studied area are shown in Figure 4. Despite the increase taxonomic richness of saprophages representatives comparatively with Plot \# 1, they are half of total mesofauna population. Zoophages and phytophages are accounted for $25 \%$ of total soil biota. In such conditions zoophages could not fully realize the function of regulation of invertebrates' quantity. 
Figure 4: Correlation between different functional groups of soil mesofauna in the territory of weed vegetation, JSC

"Kriviy Rig Saturnine Red Plant” (Plot \# 2)
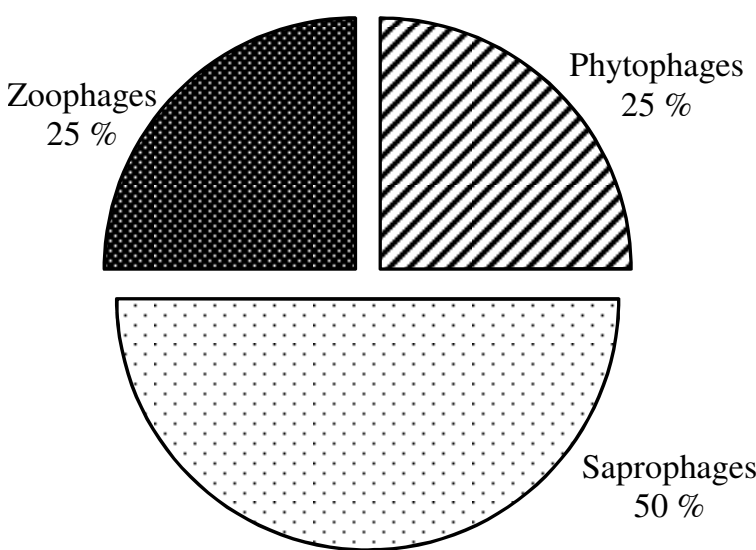

Soil mesofauna of areas JSC "Arselormyttal Steel Kriviy Rig"

Plot \# 3 is located in close proximity to sources of pollution (the territory of JSC "Arselormyttal Steel Kriviy Rig"). Soil mesofauna was presented to molluscs, insects and spiders (Figure 5). Taxonomic composition of invertebrate mesofauna is similar to population of invertebrates at the areas with weed vegetation (territory JSC “Krvvyi Rig Saturnine Red Plant”)

Figure 5: Taxonomic composition of soil mesofauna representatives in artificial arboreal plantations (territory of JSC “Arselormyttal Steel Kryvyi Rig”, Plot \# 3)

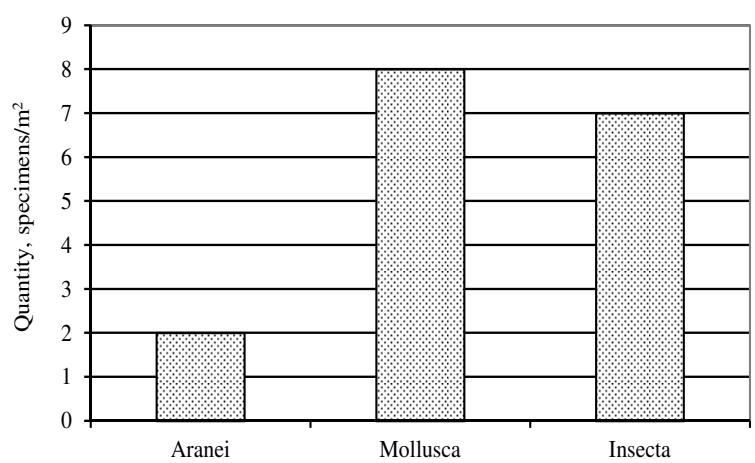

Representatives of mesofauna include 6 species of invertebrates. Total average number of these animals is 17 specimens $\mathrm{m}^{-2}$. Reducing of taxonomic diversity and species richness of mesofauna representatives at this site is explained to lack of leaf litter and large quantity of industrial dust on top the soil. Mesofauna of this area was presented predominantly animals lives on top the soil. There is observed the change correlation of representatives of different trophic groups (Figure 6).

Proportion of saprophages among other trophic groups is $47 \%$. They are represented by only one taxon. Unlike Plot \# 2 with weed plants (territory JSC "Kryvyi Rig Saturnine Red Plant") the proportion of zoophages at the studied area is increased by 1.6 times, and proportion of phytophages is decreased in 4.1 times.
Plot \# 4 (territory of JSC “Arselormyttal Steel Kryvyi Rig") had the partly carved artificial arboreal plantations. Mesofauna of this site is represented by earthworms, Gastropoda, Chilopoda, and insects (Figure 7).

Figure 6: The correlation between different functional groups of soil mesofauna in area of artificial arboreal plantations (territory of JSC “Arselormyttal Steel Kriviy Rig”, Plot \# 3)

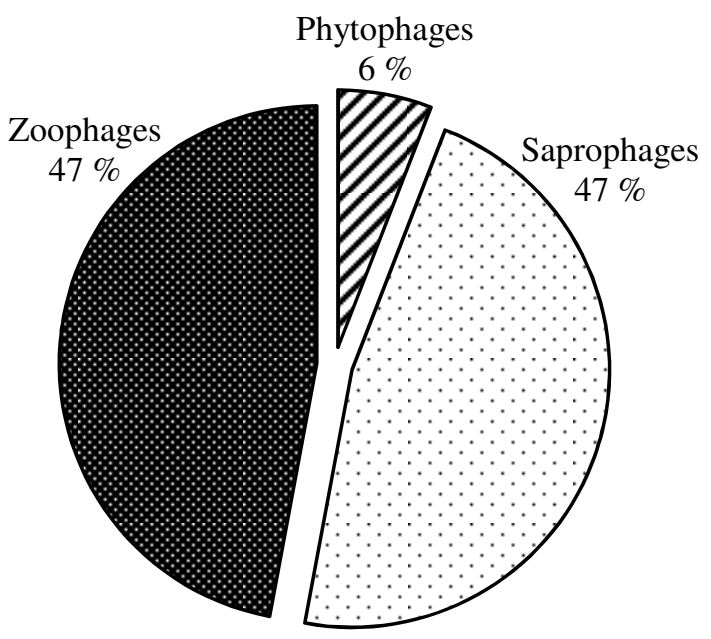

Figure 7: Taxonomic composition and abundance of soil mesofauna on Plot \# 4 of artificial arboreal plantations (territory of JSC “Arselormyttal Steel Kryvyi Rig”)

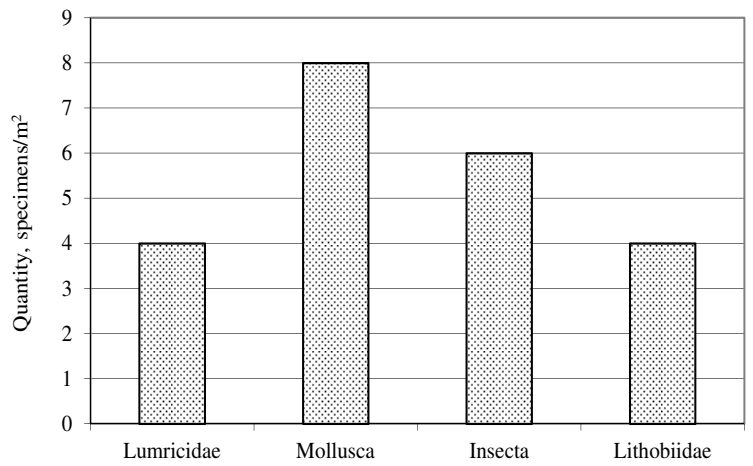

Average total number of representatives was 22 specimens $\mathrm{m}^{-2}$. Species richness of plot was 9 species of soil invertebrates. The number of mesofauna representatives varied from 2 to 4 specimens $\mathrm{m}^{-2}$. There are representatives of Lumricidae are appeared, which were absent at the Plot \# 3 of JSC "Arselormyttal Steel Kryvyi Rig" and at the Plot \# 2 of JSC "Kryvyi Rig Saturnine Red Plant".

Representatives of earthworms (Lumricidae) and Lithobiidae amounted to $18 \%$ of the total soil mesofauna, molluscs $-36 \%$, insects $-25 \%$. Insects were represented by Carabidae, Formicidae, Silphidae. Dominant groups of soil mesofauna in all four territories were molluscs and insects, subdominants - earthworms and centipedes. Saprophages were more than half of invertebrate species (Figure 8). Representatives of zoophages are comprised $36 \%$, phytophages $-9 \%$ of all species of soil biota. 
Figure 8: Correlation between different trophic groups of soil mesofauna in the area of artificial arboreal plantations (territory of JSC “Arselormyttal Steel Kryvyi Rig”, Plot \# 4)

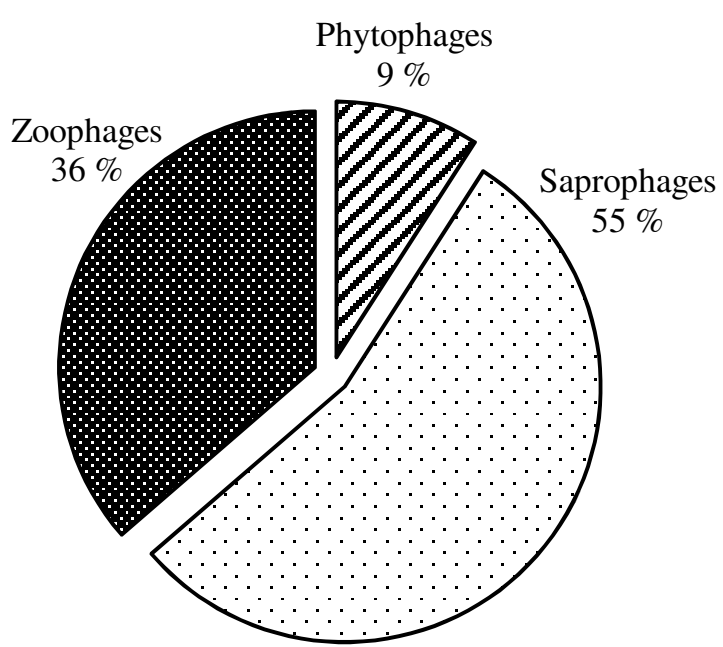

\section{CONCLUSIONS}

As a result of technogenic activity on the Kryvyi Rig territory the fundamental changes in natural landscapes occurred. On the newly-created landscapes functions of natural soils belong to technogenically modified substrates. These substrates and technogen soils were characterized by low content of humus and elements of plant nutrition, dramatic reduction of fertility, increased quantity of industrial substances, including toxic. Transformations of soil cover on territories under intensive human impact displayed on all components of ecosystems.

Activity of such largest mining and metallurgical complexes as for JSC "Kryvyi Rig Saturnine Red Plant" and "Arselormyttal Steel Kryvyi Rig" conducted to formation of various man-made landscapes directly impacting on the specificity of biota development. It was found that a small thickness of soil layer as a habitat for animals on re-cultivated grounds causes the depletion of taxonomic composition, species richness and decrease the total number of soil invertebrates. Thus, on the Plot \# 2 into layer $10-15 \mathrm{~cm}$ of humus soil above the gravel was observed the simplification of soil invertebrates' structural organization compared with Plot \# 1 where thickness of humus soil has been $30 \mathrm{~cm}$.

By products of the metal and chemical factories negatively influence the environment and reduce the useful properties of soils (changes in soil texture, for example). It is displayed on the condition of soil mesofauna. Thus, the number of insects, molluses and spiders reduced on the Plot \# 3 (where are main factors of human impact were pollution and sedimentation of dust slag) compared to Plot \# 1 (where is the main factor of human impact was contamination of saturnine red which is a dense material).

Under such conditions of the studied areas the saprophages have a leading role in formation of soil mesofauna functional groups. Gastropoda in conditions of technogen pressure (Kryvyi Rig region) is the most groups of invertebrates adapted to stresses. It is proved by their large quantity on the all investigated plots.

The obtained results are recommended to use for zoological monitoring of technogenically broken territories.

\section{ACKNOWLEDGEMENTS}

This study was supported by Hungarian-Ukrainian Intergovernmental S\&T Cooperation Programme for 2009-2010" R\&D bilateral project "Change of soils ecological characteristics of Ukraine and Hungary in the conditions of anthropogenic transformed ecosystems and optimization of biological processes of plants primary feed elements mobilization."

\section{REFERENCES}

Воробейчик, Е. Л. (1998): Население дождевых червей (Lumbricidae) лесов Среднего Урала в условиях загрязнения выбросами медеплавильного комбината. Экология. 2: 102-108.

Зубов, А. Р.-Зубова, Л. Г.-Воробьев, С. Г. (2007): Применение ГИС-техгнологий для оценки последствий воздействия угольных шахт на окружающую среду. Географічні інформаційні системи в аграрних університетах (GISAU): Матеріали 2-ої Міжнародної науково-методичної конф. Херсон. Україна. 21-22: 19-23.

Криволуцкий, Д. А. (1994): Почвенная фауна в экологическом контроле. Москва. Наука. 240.

Леонов, П. А.-Сурначев, Б. А. (1970): Породные отвалы угольных шахт. Москва. Недра. 110.

Малахов, І. М. (2003): Проблема незворотності трансформації навколишнього середовища Кривбасу. [In: Малахов, I. М. Проблеми екології та екологічної освіти: Матеріали 2 Міжнар. Наук.-Прак. Конф.] Кривий Ріг. 10-18.
Миркина, Т. Ю.-Бачинская, Л. А.-Калинина, О. В. (2003): Оптимизация пространственной и возрастной структуры искусственных популяций насекомых в условиях техногенеза. Биоразнообразие и роль зооценоза в естественных и антропогенных экосистемах: 2 Междунар. Науч. Конф.] Днепропетровск: ДНУ. 133.

Сметана, О. М.-Сметана, М. Г. (2005): Структура наземної мезофауни Кривбасу. Фітосоціоцентр. 226.

Сметана, О. М. (2007): Біогеоценотичний покрив ландшафтнотехногенних систем Кривбасу. [In: Сметана, О. М.-Перерва. В. В. Кривий Ріг: Видавничий дім.] 247.

Травлеев, А. П. (2000): Деструктивные экологические сети и перспективы их оптимизации. [In: Травлеев, А. П.-Белова, Н. А. Питання степового лісознавства та лісової рекультивації земель.] Дніпропетровськ: ДНУ. 5-17. 